\title{
Effects of raw propolis or water and ethanol extracts of propolis on performance, immune system, and some blood parameters of broiler breeders
}

\author{
Hasan Alp Sahin ${ }^{1}$, Ergin Ozturk ${ }^{1 *}$ iD \\ ${ }^{1}$ Ondokuz Mayis University, Faculty of Agriculture, Department of Animal Science, Samsun, Turkey.
}

\begin{abstract}
The objective of this study was to determine the effects of raw bee propolis and water or ethanol extract of propolis on growth performance, some blood parameters, and immunoglobulins in 15-20-week-old Ross-308 broiler breeders. The birds in the control were fed a diet without propolis, whereas the birds in the treatment groups were fed diets with raw propolis (RP), water (WEP), and ethanol (EEP) extract of propolis at the level of 1200, 400, and 400 ppm, respectively. Raw propolis and propolis extracts did not affect body weight gain, feed intake, feed conversion ratio, and some blood parameters, such as aspartate aminotransferase, alanine aminotransferase, total antioxidant status, triglyceride, and phosphorus. Birds fed EEP and those in control group had a lower IgA value compared with birds fed RP. Birds fed RP had higher IgM level than those of the other groups, and birds fed EEP had lower IgM level than those of control and RP-fed group. The IgY value of breeders fed EEP was higher than those of the other treatment birds, whereas that of WEP-fed birds was higher than those of control and RP treatment. The antibody levels of Anti-Newcastle disease virus and anti-infectious bursal disease virus were higher in EEP and RP-fed groups than those in the control and WEP-fed groups. The WEP decreased total oxidant status value compared with the control and RP treatments, whereas EEP and WEP increased plasma total protein and calcium contents compared with the control. The EEP increased plasma albumin content compared with RP. The addition of propolis extracts, especially WEP and EEP, to diet improves immunity and antioxidant activity, as well as enhances $\mathrm{Ca}$ absorption of broiler breeders.
\end{abstract}

Key Words: bee product, blood chemistry, immune parameter, performance, poultry breeder

\section{Introduction}

The main purpose of the growth of broiler breeders is to create a uniform flock in terms of high egg production and hatchability. As known, the rapid growth before the laying period is limited by feed restriction to ensure the health and reproductive capacity of birds (Mench, 2002; De Jong and Jones, 2006). Comfort, the immune system, and some other production traits of chickens are influenced negatively when they are exposed to stress due to feed restriction (D'Eath et al., 2009). Therefore, there is a close relationship between the continuity of productive and profitable production and the comfort and immune system of the animal during the growing and pullet periods. Some strategies, such as decreasing the energy content or dilution of the diet (Van Krimpen et al., 2009) and declining of voluntary feed intake (Van Krimpen and De Jong, 2014)

Received: September 6, 2017

Accepted: April 16, 2018

*Corresponding author: eozturk@omu.edu.tr

Copyright (C) 2018 Sociedade Brasileira de Zootecnia. This is an Open Access article distributed under the terms of the Creative Commons Attribution License (http://creativecommons.org/licenses/by/4.0/), which permits unrestricted use, distribution, and reproduction in any medium, provided the original work is properly cited. are applied to improve animal comfort or to reduce stress. Recently, the use of diets supplemented with feed additives assumed to boost the immune system and improve comfort is investigated as another application in broiler breeder nutrition. In this context, medicinal and aromatic plants and their extracts with antimicrobial and antioxidant properties are thought to be effective on the performance and immune systems of animals in the grower period of breeders (Fan et al., 2010, 2012; Licciardi and Underwood, 2011; Rahimi et al., 2011; Eyng et al., 2013). Therefore, to eliminate this pressure on broiler breeder chickens, a series of research is still required on various feed additives such as bee products (Eyng et al., 2015; Ozturk et al., 2015; Konanç and Ozturk, 2016; Kop Bozbay et al., 2016).

Propolis, a resinous or a wax-like substance used for hive cleaning and insulation by bees, is known for its antibacterial and antifungal properties (Fan et al., 2010, 2012; Eyng et al., 2015; Li et al., 2015; Yang et al., 2015) and stimulating effects on immune system (Denli et al., 2005; Yang et al., 2015). Therefore, researchers have focused on using propolis as feed addtive in broiler diets.

As known, immunoglobulins (Ig) such as $\operatorname{IgM}, \operatorname{IgA}$, and IgY are the main defense system in the animal body. It has been reported that some feed additives affect positively 
these defense systems in the animal body (Ziaran et al., 2005; Fan et al., 2010; Licciardi and Underwood, 2011; Rahimi et al., 2011; Fan et al., 2012; Eyng et al., 2013; Li et al., 2015). There is not enough knowledge related to the effects of propolis and its extracts on the immune status in broiler breeders. Because of these features, propolis can be used as an alternative source for broiler breeders during the pre-laying period. Therefore, this research was conducted to determine the effects of propolis and its extracts on performance, immune system parameters, levels of pathogen-specific antibodies such as anti-Newcastle disease virus (NDV) and anti-infectious bursal disease virus (IBDV), and some blood biochemistry parameters in the pre-laying period of broiler breeders.

\section{Material and Methods}

This research was carried out at an experimental farm in Samsun, Turkey, situated at 4121'53.9" N, 36¹1'16.1" E, and $150 \mathrm{~m}$ above sea level. A total of 48 female broiler breeders obtained from a local commercial firm were used. Research on animals was conducted according to the Animal Experimental Guidelines of the Ethical Committee of our university (2014/43). Broiler breeder chickens raised in ground pens until 12 weeks of age were fed a propolisfree commercial diet according to Ross-308 Breeders rearing guideline. Broiler breeders were distributed into four groups of 12 birds each. Afterwards, they were kept for three weeks in individual cages until their 15 th week of age (adaptation period). Hence, the experiment lasted for six weeks during 15-20 weeks of age. All birds were maintained at approximately $21{ }^{\circ} \mathrm{C}$ during the experiment. Birds were housed in individual cages with plastic feeders and nipple drinkers. Pullets were reared on constant day lengths of $8 \mathrm{~h}$ from 15 to 19 weeks and $11 \mathrm{~h}$ at 20 weeks of age.

All birds were fed basal diets consisted of corn, wheat, soybean meal, and sunflower meal according to recommendation of producing company. The diets were prepared as isocaloric and isonitrogenous (11.72 MJ metabolizable energy and $150 \mathrm{~g}$ crude protein $/ \mathrm{kg}$ diet) (Table 1). During the grower period, all birds were housed in sanitary conditions with ad libitum access to water from nipple drippers.

In the study, the amount of extracts supplemented to diets was adjusted according to Ozturk et al. (2015), who found that the minimum concentration of propolis extract for boosting the immune status of broiler breeders was $400 \mathrm{mg}$ per $\mathrm{kg}$ of diet. Birds in the control group were fed a diet without propolis, whereas birds in the other treatment groups were fed diets with raw propolis (RP), water
(WEP), or ethanol (EEP) extracts of propolis at the level of 1200,400 , and 400 ppm, respectively. Since approximately 400 cc WEP or EEP may be obtained from RP of $1200 \mathrm{~g}$ (Konanç and Ozturk, 2016), powder propolis was included in the RP diet at a level of $1200 \mathrm{mg} \mathrm{kg}^{-1}$, regardless of active compounds. Because the restricted feeding programme is compulsory in the grower period of broiler breeders, the amount of diet offered to all the birds were 434, 455, 490, 525,567 , and $616 \mathrm{~g} /$ bird for the $1 \mathrm{st}, 2 \mathrm{nd}, 3 \mathrm{rd}, 4 \mathrm{th}, 5 \mathrm{th}$, and 6 th week of the experiment, respectively). The basal ration was prepared weekly, and propolis and its extracts were mixed to the basal diet daily and kept at room temperature. The RP was grounded and then premixed and added to the diet. The EEP and WEP were topdressed uniformly to the diets and then this diet was mixed.

Raw propolis and ethanol and water extracts of propolis were provided by a commercial firm (Fanus, Trabzon). While the RP was stored at $-20^{\circ} \mathrm{C}$, EEP and WEP were stored at $+4{ }^{\circ} \mathrm{C}$ in a dark glass tube until the beginning of the trial. The RP used in this study was analysed for dry matter, ash, ether extracts (AOAC, 1990), dry residue (Hogendoorn et al., 2013), waxes, ethanol-insoluble residues (Cunha et al., 2004), and phenols and flavonoids (Kartal et al., 2002). Active compounds of EEP and WEP (Table 2) were analysed with gas chromatography-mass spectrometry, as explained by Ramnath et al. (2015).

Vaccines were administered in accordance with the recommendation of the company as 1 st day live ND+IB

Table 1 - Proportions of ingredients and chemical composition of the experimental diet

\begin{tabular}{lclc}
\hline Ingredient & $\mathrm{g} \mathrm{kg}^{-1}$ & $\begin{array}{c}\text { Calculated nutrient composition } \\
\left(\mathrm{g} \mathrm{kg}^{-1}\right)\end{array}$ \\
\hline Maize & 520.98 & ME $\left(\mathrm{kcal} \mathrm{kg}^{-1}\right)$ & 2800 \\
Wheat bran & 110.65 & Crude protein & 150.0 \\
Corn without semolina & 100.00 & Ether extract & 30.0 \\
Sunflower meal (36\%) & 100.00 & Crude fibre & 48.6 \\
Soybean meal (48\%) & 78.45 & Ash & 52.0 \\
Wheat & 60.00 & Available phosphorus & 4.20 \\
Limestone & 10.14 & Calcium & 9.00 \\
Monocalcium phosphate & 7.65 & Methionine & 3.20 \\
Vitamin-mineral premix & 3.00 & Methionine + cysteine & 6.22 \\
Sodium chloride & 2.20 & Lysine & 7.40 \\
Vegetable oil & 1.81 & Arginine & 9.69 \\
L-lysine (99\%) & 1.67 & Tryptophan & 1.75 \\
Vitamin D3 & 1.00 & Threonine & 5.65 \\
Organic mineral & 1.00 & Isoleucine & 5.85 \\
Sodium bicarbonate & 0.71 & Linoleic acid & 13.25 \\
DL-methionine & 0.47 & Potassium & 6.34 \\
Threonine & 0.27 & Chlorine & 2.02 \\
\hline ME & & &
\end{tabular}

ME - metabolizable energy.

${ }^{1}$ Provides per kg of diet: Mn, $80 \mathrm{mg}$; Zn, $60 \mathrm{mg}$; Fe, $60 \mathrm{mg}$; Cu, $5 \mathrm{mg}$; Co, $0.2 \mathrm{mg}$; I, $1 \mathrm{mg}$; Se, $0.29 \mathrm{mg}$; choline chloride, $200 \mathrm{mg}$; vitamin A, 12,000 IU; vitamin D3, 2,400 IU; vitamin E, $50 \mathrm{mg}$; vitamin K3, $4 \mathrm{mg}$; vitamin B1, $3 \mathrm{mg}$; vitamin B2, $6 \mathrm{mg}$; niacin, $25 \mathrm{mg}$; calcium D-pantothenate, $10 \mathrm{mg}$; vitamin B6, $5 \mathrm{mg}$; vitamin B12, $0.03 \mathrm{mg}$; D-biotin, $0.05 \mathrm{mg}$; folic acid, $1 \mathrm{mg}$. 
Table 2 - Chemical composition of raw propolis and active components of ethanol extracted propolis and water extracted propolis

\begin{tabular}{lccc}
\hline & RP & EEP & WEP \\
\hline Chemical composition $\left(\mathrm{g} \mathrm{kg}^{-1} \mathrm{DM}\right)$ & & & \\
Dry matter $\left(\mathrm{g} \mathrm{kg}^{-1}\right)$ & 962.1 & & \\
Ash & 17.5 & & \\
Dry residue & 689.8 & & \\
Waxes & 235.5 & & \\
Ether extract & 407.1 & & \\
Crude protein & 54.18 & & \\
Ethanol-insoluble residue & 598.8 & & \\
Phenols & 57.8 & & \\
Flavonoids & 11.1 & & \\
Active compounds (\%) & & & \\
Alcohols & & 2.09 & 9.67 \\
Sugars (monosaccharide) & & 1.48 & 1.01 \\
Carboxylic acids and esters & & 47.73 & 25.77 \\
Hydrocarbon & & 14.18 & 7.73 \\
Phenols & & 12.36 & 7.12 \\
Flavonoids & & 7.69 & 2.27 \\
Terpenoids & & 1.59 & 4.82 \\
Other chemicals & & 12.88 & 41.61 \\
\hline
\end{tabular}

DM - dry matter; RP - raw propolis; EEP - ethanol extracted propolis; WEP - water extracted propolis.

${ }^{1} 128$ and 38 chemical components less than $1 \%$ for EEP and WEP, respectively.

Sprey, 18th day live infectious bursal disease (IBD) drinking water, 21st day live ND+IB Spray, 26th day live IBD drinking water, 49th day live ND+IB Spray, and 126th day inactive IBD+ND intramuscular. The anti-NDV and anti-IBDV antibody levels were determined using NDV test ELISA kit and IBDV test ELISA kit, respectively. Blood samples were collected from 20-week-old female Ross-308 breeder hens. For plasma of dams, antibody levels means were based on 12 hens. The values were expressed as sample:positive (S:P) ratio.

At the end of the experiment, blood samples $(10 \mathrm{mg})$ were taken from the bronchial vein of all birds with 22-gauge injectors into the lithium heparin tubes. Plasma samples were separated from the tubes by centrifuging the blood at $1550 \times g$ for $10 \mathrm{~min}$ at $4{ }^{\circ} \mathrm{C}$. The separated plasma samples were transferred and stored at $-20{ }^{\circ} \mathrm{C}$ until analysis. The $\operatorname{IgY}, \operatorname{IgA}$, and IgM levels of the plasma were determined using quantitive ELISA kits as explained by Konanç and Ozturk (2016). The procedures of blood sample collection and antibody extraction, determination of anti-NDV and anti-IBDV antibodies, and calculation of the S:P ratio were designed according to Hamal et al. (2006). The sample to positive ratio was calculated as using mean absorbance (MA) of the sample, negative control, and positive control.

$$
\frac{\mathrm{S}}{\mathrm{P}} \text { ratio }=\frac{\mathrm{MA} \text { of the sample }-\mathrm{MA} \text { of the negative control }}{\mathrm{MA} \text { of the positive control }- \text { MA of the negative control }}
$$

The total protein, albumen, triglyceride, $\mathrm{Ca}, \mathrm{P}$, aspartate aminotransferase (AST), and alanin aminotransferase (ALT) in plasma were analysed by an automatic analyser (Airone-200RA, Italy) using commercial kits. Total antioxidant (TAS) and total oxidant (TOS) amounts were determined by the ELISA method in plasma (Abudabos et al., 2016). The oxidative stress index was calculated by TOS:TAS ratio.

In this study, the individual birds were considered as the experimental unit for statistical analysis. Data homogenised by the Shapiro-Wilk test were analysed according to the compare means (one-way ANOVA) procedure of SPSS (version 21) program. Differences among the means were tested by Duncan's multiple range test.

\section{Results}

Propolis and its extracts did not affect body weight gain, feed intake, and feed conversion ratio (FCR) of broiler breeders (Table 3). There was no mortality during the experiment. While the group fed RP had higher IgA level than other treatment groups, except group fed WEP, the RP-fed group had a higher IgM value than the other treatment groups $(\mathrm{P}<0.05)$. The IgY value of breeders fed EEP was higher than those of birds from other treatments, whereas that of birds fed WEP was higher than those of the control and RP treatments $(\mathrm{P}<0.05)$. Levels of anti-NDV and anti-IBDV antibodies as the S:P ratio were higher in EEP- and RP-fed groups than those of the control and WEP treatment $(\mathrm{P}<0.05)$ (Table 4). Raw propolis and EEP did not affect plasma AST, ALT, TAS, trigliceride, and P-values (Table 5). While birds fed diet with WEP had a lower TOS level than control and RP-fed birds, birds fed EEP and WEP had higher plasma protein and Ca levels compared with control birds $(\mathrm{P}<0.05)$. The plasma albumin level of birds in the EEP-fed group was higher than those in the RP treatment $(\mathrm{P}<0.05)$.

Table 3 - Body weight (BW), body weight gain (BWG), feed intake (FI), and feed conversion ratio (FCR) of broiler breeders fed diets supplemented with propolis and its extracts from 16 to 20 weeks of age

\begin{tabular}{lcccccc}
\hline & Control & EEP & WEP & RP & SEM & P-value \\
\hline Initial BW $(\mathrm{g})$ & 1395 & 1424 & 1399 & 1403 & 12.09 & 0.852 \\
Final BW $(\mathrm{g})$ & 2108 & 2138 & 2067 & 2152 & 13.71 & 0.119 \\
BWG $(\mathrm{g})$ & 713 & 714 & 668 & 748 & 14.87 & 0.269 \\
FI $(\mathrm{g})$ & 3087 & 3087 & 3087 & 3087 & ND & ND \\
FCR (g feed:g BWG) & 4.33 & 4.32 & 4.62 & 4.12 & 0.10 & 0.29 \\
\hline
\end{tabular}

EEP - ethanol extracted propolis; WEP - water extracted propolis; RP - raw propolis; SEM - standard error of the mean; ND - not determined (because basal diet was offered equally to all groups). 
Table 4 - Plasma levels of immunoglobulins (IgA, IgM, and IgY) and sample:positive ratio of anti-Newcastle disease virus (NDV) and anti-infectious bursal disease virus (IBDV) antibodies in female broiler breeders fed diets supplemented with propolis or its extracts

\begin{tabular}{lcccccc}
\hline Antibody type & Control & EEP & WEP & RP & SEM & P-value \\
\hline $\operatorname{IgA}\left(\mu \mathrm{mL}^{-1}\right)$ & $103.75 \mathrm{~b}$ & $105.99 \mathrm{~b}$ & $121.52 \mathrm{ab}$ & $150.32 \mathrm{a}$ & 6.204 & 0.024 \\
$\operatorname{IgM}\left(\mu \mathrm{mL}^{-1}\right)$ & $141.60 \mathrm{~b}$ & $93.73 \mathrm{c}$ & $124.60 \mathrm{bc}$ & $188.74 \mathrm{a}$ & 8.205 & $<0.0001$ \\
$\operatorname{IgY}\left(\mathrm{mg} \mathrm{mL}^{-1}\right)$ & $82.48 \mathrm{c}$ & $161.10 \mathrm{a}$ & $126.86 \mathrm{~b}$ & $70.16 \mathrm{c}$ & 9.291 & $<0.0001$ \\
Anti-NDV antibody $^{1}$ & $2.94 \mathrm{~b}$ & $3.35 \mathrm{a}$ & $2.79 \mathrm{~b}$ & $3.42 \mathrm{a}$ & 0.079 & 0.009 \\
Anti-IBDV antibody $^{1}$ & $3.45 \mathrm{~b}$ & $3.88 \mathrm{a}$ & $3.63 \mathrm{~b}$ & $3.89 \mathrm{a}$ & 0.069 & 0.049 \\
\hline
\end{tabular}

EEP - ethanol extracted propolis; WEP - water extracted propolis; RP - raw propolis; SEM - standard error of the mean.

${ }^{1}$ Determined using ELISA kits.

a-c - Values in rows with different letters differ significantly $(\mathrm{P}<0.05)$.

Table 5 - Selected plasma parameters of broiler breeders fed diets with propolis and its extracts

\begin{tabular}{lcccccc}
\hline Parameter & Control & EEP & WEP & RP & SEM & P-value \\
\hline TAS $\left(\mathrm{mmol} \mathrm{L}^{-1}\right)$ & 1.26 & 1.35 & 1.52 & 1.57 & 0.052 & 0.138 \\
TOS $\left(\mu \mathrm{mol} \mathrm{L}^{-1}\right)$ & $7.57 \mathrm{a}$ & $6.33 \mathrm{ab}$ & $5.70 \mathrm{~b}$ & $7.53 \mathrm{a}$ & 0.289 & 0.049 \\
TOS:TAS ratio & 5.65 & 5.32 & 4.69 & 4.64 & 0.433 & 0.385 \\
Triglyceride $\left(\mathrm{mg} \mathrm{dL}^{-1}\right)$ & 87.63 & 98.86 & 95.92 & 83.74 & 2.768 & 0.189 \\
Total protein $\left(\mathrm{g} \mathrm{dL}^{-1}\right)$ & $5.56 \mathrm{~b}$ & $6.50 \mathrm{a}$ & $6.60 \mathrm{a}$ & $5.82 \mathrm{ab}$ & 0.149 & 0.025 \\
Albumin $\left(\mathrm{g} \mathrm{dL}^{-1}\right)$ & $2.58 \mathrm{ab}$ & $2.79 \mathrm{a}$ & $2.52 \mathrm{ab}$ & $2.30 \mathrm{~b}$ & 0.076 & 0.038 \\
AST $\left(\mathrm{IU} \mathrm{L}^{-1}\right)$ & 219.20 & 222.91 & 229.70 & 230.88 & 4.646 & 0.870 \\
ALT $\left(\mathrm{IU} \mathrm{L}^{-1}\right)$ & 4.19 & 3.42 & 4.05 & 4.25 & 0.143 & 0.161 \\
$\mathrm{Ca}\left(\mathrm{mg} \mathrm{dL}^{-1}\right)$ & $6.25 \mathrm{~b}$ & $7.60 \mathrm{a}$ & $7.93 \mathrm{a}$ & $7.22 \mathrm{ab}$ & 0.226 & 0.039 \\
$\mathrm{P}\left(\mathrm{mg} \mathrm{dL}^{-1}\right)$ & 4.81 & 5.19 & 4.96 & 4.56 & 0.133 & 0.449 \\
\hline
\end{tabular}

EEP - ethanol extracted propolis; WEP - water extracted propolis; RP - raw propolis; SEM - standard error of the mean; TAS - total antioxidant status; TOS - total oxidant status; AST - aspartate amino transferase; ALT - alanin amino transferase. a-c - Values in rows with different letters differ significantly $(\mathrm{P}<0.05)$.

\section{Discussion}

The results of the present study indicate that the addition of propolis extract, especially ethanol and water extracts, in the diet improves immunity and antioxidant activity as well as enhances $\mathrm{Ca}$ absorption. In the present research, body weight gain and feed intake values were not affected by using propolis or its extracts (Table 3). This may be related to many factors (Ramnath et al., 2015; Konanç and Ozturk, 2016) that affect propolis characteristics and, most probably, the feeding system applied for controlling growth rate in the present study. Many researchers have reported that diets supplemented with propolis affected body weight gain, feed intake, and FCR of broilers positively (Roodsari et al., 2004; Shalmany and Shivazad, 2006; Tekeli et al., 2011; Seven et al., 2012; Attia et al., 2014). In contrast to these researchers, Duarte et al. (2014) reported that propolis did not affect broiler performance. Acikgöz et al. (2005) and Danesgmand et al. (2015) reported a decrease in the growth performance of broilers fed diets supplemented with propolis and EEP, respectively. The differences among the studies in terms of bird performance might be attributed to the origin, chemical composition, phenolic compounds, and dose of propolis, age or rearing period of animal, and feeding system applied. For example, broiler breeders used in our study were 15-20 weeks old, whereas broiler chickens used in the other studies were 1-42 days old.

The results in relation to immunoglobulin levels indicated that the addition of propolis extracts to the diet affected the immune status of birds, especially in the EEP treatment group. Some researchers (Ziaran et al., 2005; Fan et al., 2013; Attia et al., 2014; Li et al., 2015; Ozturk et al., 2015; Yang et al., 2015) reported that propolis positively affected the immune status of broilers. The beneficial effect of propolis may be related to its bioactive compounds such as aromatic acids, flavonoids, terpenoids, alkaloids, and polyphenols due to their immunomodulatory properties (Raphael and Kuttan, 2003). Therefore, the role of bioactive compounds in the immunological system may be explained by the fact that the EEP is able to activate macrophages, providing a first line of defense against microorganisms, promote the production of antibodies, and boost the immune response (Raphael and Kuttan, 2003; Kalsum et al. 2017). Therefore, our results indicate that propolis has an immunostimulatory potential for broiler breeders.

Our results with respect to the S:P ratio agree with the suggestion of Wang et al. (2006), who demonstrated that some feed additives, including flavones such as chines herbal plants and propolis, in the diets of male chickens (White Roman) increased antibody levels compared with the control group. Moreover, it has been determined that birds fed a diet fortified with oil-extracted propolis had a higher antibody level and a better response to avian influenza, NDV, and IBD vaccines than those in the control group (Taheri et al., 2005). Therefore, it can be said that humoral immunity and the success of vaccination can be improved by propolis supplementation to the diets of parents. In contrast to results of previous (Taheri et al., 2005; Wang et al., 2006) and present studies, Konanç and Ozturk (2016) obtained similar titer values for only IBDV in broilers fed diet with EEP. The discrepancy between the studies may be related to the fact that broiler breeder hens had a longer life for vaccination program compared with broilers.

Total antioxidant and TOS are known as the most important features of the antioxidant system, because they have free radical scavenging activity in live organisms. A decrease in TOS level of WEP-fed birds compared with birds from control and RP treatment shows that the antioxidant features of RP and control was not high as much as efficiency of WEP to boost the immune system of 
the birds. These differences in response to the extract forms may be related to the fact that there is a difference among the propolis extracting methods in terms of obtained active compounds, as in the present study. Based on this result, to combine the beneficial effects of both propolis extracts, the use of their blends can be suggested.

The effect of propolis on antioxidant status may be dependent on decreasing malondialdehyde and lipid peroxidation in plasma, liver, and muscle tissue (Matsui et al., 2004; Seven et al., 2010; Babińska et al., 2013), although the extracts did not affect ALT levels. The result with regard to levels of plasma trigliceride are similar to the results of previous studies (Biavatti et al., 2003; Denli et al., 2005). They reported that propolis or its extracts did not affect plasma trigliceride of quails and broilers in spite of the use of higher dose of propolis in their diets (1000 and 3000 ppm). In contrast, in recent studies, propolis caused a decrease in blood triglyceride level in broilers and layers (Galal et al., 2008; Babińska et al., 2013; Attia et al., 2014). These differences may be attributed the anti-oxidising properties of propolis, considered to improve lipid metabolism, liver morphological structures, and biological functions, and also differences in metabolic rate of animal species (Matsui et al., 2004; Babińska et al., 2013). Indeed, broiler breeders can be exposed to liver diseases because of their high metabolic rates. In the present study, the fact that indicators of liver damage such as AST and ALT were not affected by the treatments may be resulted from a decrease in the metabolic rate due to the feed restriction, as reported in quails (Silici et al., 2013) and broilers (Attia et al., 2014).

Total protein and albumin content are very important in evaluating and interpreting the effects, related directly to animal health and nutrition of feed additives (Ozturk et al., 2012). Conflicting results have been reported about the impact of propolis on total protein and albumin content in different poultry species (Galal et al., 2008; Tatli Seven, 2008; Abdel-Rahman and Mosaad, 2013). Therefore, our results on the total protein and albumin contents indicate that propolis and its extracts have variable effects on these parameters. However, an increase the total protein contents due to supplementation of EEP and WEP indicate that propolis extracts may stimulate the synthesis and release of immunoglobulins by increasing the absorption of protein in the gastrointestinal tract. However, the fact that RP did not affect total protein contents may be related to the digestibility, solubility, and biological activity of raw propolis or its components. Variation in results may be due to differences in the quality of propolis itself (type, dose, form, plant species, location, and season), experimental birds (species, age, gender, stress, heat, and management), and other factors such as time point and duration of propolis application (Bankova, 2005; Mahmoud et al., 2016). Moreover, as reported by Mahmoud et al. (2016), it is very difficult to adequately compare studies in which propolis was used as a feed additive, since active compound analyses were not done in many of these studies.

Pre-laying diets and pre-laying management are designed to allow the bird the opportunity to establish adequate medullary bone reserves required for calcifying the first egg. One of the major management decisions today is the actual need for pre-laying diets or whether pullets can sustain long-term shell quality when moved from a grower to a high-calcium layer diet (Leeson and Summers, 2005). A portion of the required calcium for shell calcification will come from medullary bone reserves. Therefore, an increase in the blood $\mathrm{Ca}$ content of birds fed propolis extracts at the pre-laying period may cause calcium to be released for shell synthesis during the laying period

Our results with respect to calcium, IgY, antibody, oxidant, AST, and ALT levels in the blood support idea that propolis extracts, particularly EPP, boosted the immune system, reduced oxidants, and improved $\mathrm{Ca}$ absorption of broiler breeder pullets. The egg shell quality decreases during late laying period especially in breeders. Further research is needed to determine whether the increases in $\mathrm{Ca}$ absorption due to use of propolis extracts observed in pullet period (16-20 weeks) can also be seen during late laying period.

\section{Conclusions}

The addition of propolis extract, especially water and ethanol, to diet improves immunity and antioxidant activity as well as enhances $\mathrm{Ca}$ absorption, without affecting blood parameters such as aspartate aminotransferase, alanin aminotransferase, triglyceride, and phosphorus. Body weight gain, feed intake, and feed conversion ratio of broiler breeders are not changed by supplementation of propolis and its extracts in the conditions of the current experiment.

\section{Acknowledgments}

This study was supported by Ondokuz Mayis University Research Fund (Project number 1901.15.004). The authors are grateful to Israfil Aksan, for checking English grammar. This article was summarised from the MSc thesis of H. A. Sahin.

\section{References}

Abdel-Rahman, M. A. and Mosaad, G. M. 2013. Effect of propolis as additive on some behavioural patterns, performance and blood 
parameters in Muscovy broiler ducks. Journal of Advanced Veterinary Research 3:64-68.

Abudabos, A. M.; Alyemni, A. H. and Zakaria, H. A. H. 2016. Effect of two strains of probiotics on antioxidant capacity, oxidative stress and immune responses in salmonella-challenged broiler chicks. Brazilian Journal of Poultry Science 18:175-180.

Acikgöz, Z.; Yücel, B. and Altan, O. 2005. The effects of propolis supplementation on broiler performance and feed digestibility. Archiv fur Geflugelkunde 69:117-122.

AOAC - Association of Official Analytical Chemists. 1990. Official methods of analysis of the AOAC. 15th ed. Association of Official Analytical Chemists, Arlington, VA, USA.

Attia, Y.; Al-Hamid, A. E.; Ibrahim, M. S.; Al-Harthi, M. A.; Bovera, F. and Elnaggar A. S. 2014. Productive performance, biochemical and hematological traits of broiler chickens supplemented with propolis, bee pollen, and mannan oligosaccharides continuously or intermittently. Livestock Science 164:87-95. https://doi. org/10.1016/j.livsci.2014.03.005

Babińska, I.; Kleczek, K.; Makowski, W. and Szarek, J. 2013. Effect of feed supplementation with propolis on liver and kidney morphology in broiler chickens. Pakistan Veterinary Journal 33:1-4.

Bankova, V. 2005. Chemical diversity of propolis and the problem of standardization. Journal of Ethnopharmacology 100:114-117. https://doi.org/10.1016/j.jep.2005.05.004

Biavatti, M. W.; Bellaver, M. H.; Volpato, L.; Costa, C. and Bellaver, C. 2003. Preliminary studies of alternative feed additives for broilers: Alternanthera brasiliana extract, propolis extract and linseed oil. Revista Brasileira de Ciência Avícola 5:147-151. https://doi.org/10.1590/S1516-635X2003000200009

Cunha, I.; Sawaya, A. C.; Caetano, F. M.; Shimizu, M. T.; Marcucci, M. C.; Drezza, F. T.; Povia, G. S. and Carvalho, P. D. O. 2004. Factors that influence the yield and composition of Brazilian propolis extracts. Journal of the Brazilian Chemical Society 15:964-970. https://doi.org/10.1590/S0103-50532004000600026

Danesgmand, A.; Sadeghig, H.; Karimi, A.; Vaziry, A. I. and Ibrahim, A. 2015. Evaluating complementary effects of ethanol extract of propolis with the probiotic on growth performance, immune response and plasma metabolites in male broiler chickens. Livestock Science 178:195-201.

D’Eath, R. B.; Tolkamp, B. J.; Kyriazakis, I. and Lawrence, A. B. 2009. Freedom from hunger and preventing obesity: the animal welfare implications of reducing food quantity or quality. Animal Behaviour 77:275-288. https://doi.org/10.1016/j.anbehav.2008.10.028

De Jong, I. C. and Jones, B. 2006. Feed restriction and welfare in domestic birds. p.120-135. In Feeding in domestic vertebrates: from structure to behaviour. Bels, V, ed. 5th ed. CABI Publishing, Wallingford, UK.

Denli, M.; Cankaya, S.; Silici, S.; Okan, F. and Uluocak, A. N. 2005. Effect of dietary addition of Turkish propolis on the growth performance, carcass characteristics and serum variables of quail (Coturnix coturnix japonica). Asian-Australasian Journal of Animal Sciences 18:848-854. https://doi.org/10.5713/ajas.2005.848

Duarte, C. R. A; Eyng, C.; Murakami, A. E. and Santos, T. C. 2014. Intestinal morphology and activity of digestive enzymes in broilers fed crude propolis. Canadian Journal of Animal Science 94:105-114. https://doi.org/10.4141/cjas2013-059

Eyng, C.; Murakami, A. E.; Pedroso, R. B.; Silveira, T. G. V.; Lourenco, D. A. L. and Garcia, A. F. Q. M. 2013. Crude propolis as an immunostimulating agent in broiler feed during the starter phase. Semina: Ciências Agrárias 34:2511-2522.

Eyng, C. U.; Murakami, A. E.; Santos, T. C.; Silveira, T. G. V.; Pedroso, R. B. and Lourenco, D. A. L. 2015. Immune responses in broiler chicks fed propolis extraction residue-supplemented diets. Asian-Australasian Journal of Animal Sciences 28:135-142. https://doi.org/10.5713/ajas.14.0066
Fan, Y.; Hu, Y.; Wang, D.; Guo, Z.; Zhao, X.; Guo, L.; Zhao, B.; Zhang, J.; Wang, Y. and Nguyen, T. L. 2010. Epimedium polysaccharide and propolis flavone can synergistically stimulate lymphocyte proliferation in vitro and enhance the immune responses to ND vaccine in chickens. International Journal of Biological Macromolecules 47:87-92. https://doi.org/10.1016/j.ijbiomac.2010.05.017

Fan, Y.; Wang, D.; Hu, Y.; Liu, J.; Han, G.; Zhao, X.; Yuan, J.; Liu, C.; Liu, X. and Ni, X. 2012. Liposome and epimedium polysaccharidepropolis flavone can synergistically enhance immune effect of vaccine. International Journal of Biological Macromolecules 50:125-130. https://doi.org/10.1016/j.ijbiomac.2011.10.008

Fan, Y.; Yu, L.; Wang, D.; Liu, J.; Song, X.; Zhang, W.; Zhao, X.; Nguyen, T. L. and Hu, Y. 2013. Effect of epimedium polysaccharidepropolis flavone immunopotentiator on immunosuppression induced by cyclophosphamide in chickens. Cellular Immunology 28:37-43. https://doi.org/10.1016/j.cellimm.2013.01.008

Galal, A.; El-Motaal, A. M.; Ahmed, A. M. H. and Zakit, G. 2008. Productive performance and immune response of laying hens as affected by dietary propolis supplementation. International Journal of Poultry Science 7:272-278. https://doi.org/10.3923/ijps.2008.272.278

Hamal, K. R.; Burgess, S. C.; Pevzner, I. Y. and Erf, G. F. 2006. Maternal antibody transfer from dams to their egg yolks, egg whites, and chicks in meat lines of chickens. Poultry Science 85:1364-1372. https://doi.org/10.1093/ps/85.8.1364

Hogendoorn, E. A.; Sommeijer, M. J. and Vredenbregt, M. J. 2013. Alternative method for measuring beeswax content in propolis from the Netherlands. Journal of Apicultural Science 57:81-90. https://doi.org/10.2478/jas-2013-0019

Kalsum, N.; Sulaeman, A.; Setiawan, B. and Wibawan, I. W. T. 2017. Preliminary studies of the immunomodulator effect of the propolis Trigona spp. extract in a mouse model. IOSR Journal of Agriculture and Veterinary Science 10:75-80 https://doi.org/10.9790/2380-1002027580

Kartal, M.; Kaya, S. and Kurucu, S. 2002. GC-MS analysis of propolis samples from two different regions of Turkey. Zeitschrift für Naturforschung C 57:905-909. https://doi.org/10.1515/znc2002-9-1025

Konanç, K. and Ozturk, E. 2016. Effects of in-ovo injection of propolis ethanol extract to the hatching eggs and its addition to offspring diets at post-hatching period on the immune system, intestinal microflora and fattening performance. Worlds' Poultry Science Journal 72(Suppl. 1):36.

Kop Bozbay, C.; Konanç, K.; Ocak, N. and Öztürk, E. 2016. The effects of in ovo injection of propolis and injection site on hatchability, hatching weight and survival of chicks. Turkish Journal of Agricultural Research 3:48-54.

Leeson, S. and Summers, J. D. 2005. Commercial poultry nutrition. 3rd ed. Nottingham University Press, Nottingham.

Li, B.; Wei, K.; Yang, S.; Yang, Y.; Zhang, Y.; Zhu, F.; Wnag, D. and Zhu, R. 2015. Immunomodulatory effects of Taishan Pinus massoniana pollen polysaccharide and propolis on immunosuppressed chickens. Microbial Pathogenesis 78:7-13. https://doi.org/10.1016/j.micpath.2014.11.010

Licciardi, P. V. and Underwood, J. R. 2011. Plant-derived medicines: a novel class of immunological adjuvants. International Immunopharmacology 11:390-398. https://doi.org/10.1016/j. intimp.2010.10.014

Mahmoud, U. T.; Cheng, H. W. and Applegate, T. J. 2016. Functions of propolis as a natural feed additive in poultry. World's Poltry Science Journal 72:37-47. https://doi.org/10.1017/S0043933915002731

Matsui, T.; Ebuchi, S.; Fujise, T.; Abesundara, K. J. M.; Doi, S.; Yamada, H. and Matsumoto, K. 2004. Strong antihyperglycemic effects of water-soluble fraction of Brazilian propolis and its bioactive constituent, 3,4,5-tri-o-caffeoylquinic acid. Biological and Pharmaceutical Bulletin 27:1797-1803. 
Mench, J. A. 2002. Broiler breeders: feed restriction and welfare. World's Poultry Science Journal 58:23-30. https://doi.org/10.1079/ WPS20020004

Ozturk, E.; Konanc, K.; Cifci, A. and Sahin, H. A. 2015. Does increase immunoglobulins in broiler breeding when added propolis to the diet? p.66. In: 7th Balkan Conference on Animal Science Balnimalcon, Sarajevo.

Ozturk, E.; Ocak, N.; Turan, A.; Erener, G.; Altop, A. and Cankaya, S. 2012. Performance, carcass, gastrointestinal tract, meat quality traits and selected blood parameters of broilers fed diets supplemented with humic substances. Journal of the Science of Food and Agriculture 92:59-65. https://doi.org/10.1002/jsfa.4541

Rahimi, S.; Zadeh, T. Z.; Karimi Torshizi, M. A.; Omidbaigi, R. and Rokni, H. 2011. Effect of the three herbal extracts on growth performance, immune system, blood factors and intestinal selected bacterial population in broiler chickens. Journal of Agricultural Science and Technology 13:527-539.

Ramnath, S.; Venkataramegowda, S. and Singh, A. A. 2015. Chemical composition of bee propolis collected from different regions in India by GCMS analysis. International Journal of Pharmacognosy and Phytochemistry 30:1319-28.

Raphael, T. J. and Kuttan, G. 2003. Immunomodulatory activity of naturally occurring monoterpenes carvone, limonene, and perillic acid. Immunopharmacology and Immunotoxicology 25:285-294.

Roodsari, M. H.; Mehdizadeh, M.; Kasmani, F. B.; Lotfelahian, H.; Mosavi, F. and Abolghasemi, A. H. 2004. Effects of oilextracted propolis on the performance of broiler chicks. Journal of Agricultural Science and Technology 18:Pe57-65.

Seven, I.; Aksu, T. and Seven, P. T. 2010. The effects of propolis on biochemical parameters and activity of antioxidant enzymes in broilers exposed to lead-induced oxidative stress. Asian-Australasian Journal of Animal Sciences 23:1482-1489. https://doi.org/10.5713/ajas.2010.10009

Seven, I.; Aksu, T. and Seven, P. T. 2012. The effects of propolis and vitamin $\mathrm{C}$ supplemented feed on performance, nutrient utilization and carcass characteristics in broilers exposed to lead. Livestock Science 148:10-15. https://doi.org/10.1016/j.livsci.2012.05.001

Shalmany, S. K. and Shivazad, M. 2006. The effect of diet propolis supplementation on Ross broiler chicks performance. International Journal of Poultry Science 5:84-88. https://doi.org/10.3923/ ijps.2006.84.88
Silici, S.; Ozkan, M.; Kara, K. and Kocaoglu, G. B. 2013. Influence of propolis, caffeic acid and ferulic acid addition to Japanese quail (Coturnix coturnix japonica) diets on performance, carcass quality and some biochemical parameters. Journal of Faculty of Veterinary Medicine, Erciyes University 10:157-164.

Taheri, H. R.; Rahmani, H. R. and Pourreza, J. 2005. Humoral immunity of broilers is affected by oil extracted propolis (OEP) in the diet. International Journal of Poultry Science 4:414-417. https://doi.org/10.3923/ijps.2005.414.417

Tatli Seven, P. 2008. The effects of dietary Turkish propolis and vitamin $\mathrm{C}$ on performance, digestibility, egg production and egg quality in laying hens under different environmental temperatures. Asian-Australasian Journal of Animal Sciences 21:1164-1170. https://doi.org/10.5713/ajas.2008.70605

Tekeli, A.; Kutlu, H. R. and Celik, L. 2011. Effects of Z. officinale and extracts on the performance, carcass and some blood parameters of broiler chicks. Current Research in Poultry Science 1:12-23. https://doi.org/10.3923/crpsaj.2011.12.23

Van Krimpen, M. M. and De Jong, I. C. 2014. Impact of nutrition on welfare aspects of broiler breeder flocks. World's Poultry Science Journal 70:139-150. https://doi.org/10.1017/S0043933914000129

Van Krimpen, M. M.; Kwakkel, R. P.; Peet-Schwering, C. M. C.; Hartog, L. A. and Verstegen, M. W. A. 2009. Effects of nutrient dilution and nonstarch polysaccharide concentration in rearing and laying diets on eating behavior and feather damage of rearing and laying hens. Poultry Science 88:759-773.

Wang, D.; Li, X.; Xu, L.; Hu, Y.; Zhang, B. and Liu, J. 2006. Immunologic synergism with IL-2 and effects of cCHMIs on mRNA expression of IL-2 and IFN- $\gamma$ in chicken peripheral T lymphocyte. Vaccine 24:7109-7114. https://doi.org/10.1016/j. vaccine.2006.07.005

Yang, Y.; Wei, K.; Yang, S.; Li, B.; Zhang, Y.; Zhu, F.; Wang, D.; Chi, S.; Jiang X. and Zhu, R. 2015. Co-adjuvant effects of plant polysaccharide and propolis on chickens inoculated with Bordetella avium inactivated vaccine. Avian Pathology 44:248-253. https://doi.org/10.1080/03079457.2015.1040372

Ziaran, H. R.; Rahmani, H. R. and Pourreza, J. 2005. Effect of dietary oil extract of propolis on immune response and broiler performance. Pakistan Journal of Biological Sciences 8:1485-1490. https://doi.org/10.3923/pjbs.2005.1485.1490 